\title{
PENGARUH INTERNAL LOCUS OF CONTROL TERHADAP KINERJA KARYAWAN DENGAN KEPUASAN KERJA SEBAGAI VARIABEL PEMEDIASI
}

\author{
Lella Anita $^{(1) *}$, Northa Idaman ${ }^{(2)}$ \\ Institut Agama Islam Negeri Metro Lampung \\ lellaanita8@gmail.com,northaidaman@metrouniv.ac.id
}

\begin{abstract}
Abstrak. Penelitian ini bertujuan untuk memberikan bukti secara empiris pengaruh internal locus of control terhadap kinerja karyawan dengan kepuasan kerja sebagai variable pemediasi. Sample penelitian ini 100 karyawan tetap dan tidak tetap pada PT PNM Cabang Lampung. Metode pengumpulan data yang digunakan dalam penelitian ini dengan menggunakan metode survey melalui pengisian kuesioner. Penelitian ini menggunakan teknik purposive sampling yang didasarkan pada kriteria tertentu. Alat analisis yang digunakan untuk menguji hipotesis adalah dengan metoda Structural Equation Model (SEM). Penggunaan model persamaan tersebut dengan aplikasi program Partial Least Squares (PLS) versi 3.0.m. Hasil penelitian menunjukkan bahwa: (1) Internal locus of control tidak berpengaruh terhadap kinerja karyawan. Hal ini tidak mendukung hipotesis. (2) Internal locus of control berpengaruh positif signifikan terhadap kepuasan kerja. Hal ini mendukung hipotesis. (3) Kepuasan kerja berpengaruh positif signifikan terhadap kinerja karyawan. Hal ini mendukung hipotesis. (4) Kepuasan kerja memediasi hubungan antara internal locus of control terhadap kinerja karyawan.
\end{abstract}

Kata Kunci: Internal locus of control, Kepuasan Kerja, Kinerja Karyawan.

\section{PENDAHULUAN}

Seiring perubahan zaman yang semakin modern menyebabkan terjadinya perubahan terhadap beberapa hal terutama pada sikap, perilaku, dan cara pandang seseorang atas beberapa peristiwa terutama pada perusahaan pembiayaan. Perkembangan perusahaan pembiayaan di Indonesia menjadi sangat pesat yang diimbangi dengan besarnya minat masyarakat untuk memenuhi kebutuhannya. Keadaan ini memicu munculanya perusahaan pembiayaan baru yang membuat persaingan usaha menjadi sangat kompetitif dan kompleks. Menurut Taormina dan Lao (2007:221) kesuksesan suatu bisnis ditentukan oleh karakteristik individual. Karakteristik individual dapat memengaruhi perilaku seseorang dalam organisasi diantaranya adalah internal locus of control. Internal locus of control merupakan salah satu dari jenis locus of control di mana seseorang beranggapan bahwa segala sesuatu peristiwa yang dialami terjadi karena tindakan individu itu sendiri.

Kualitas sumber daya manusia dapat dilihat dari seberapa baiknya kinerja karyawan secara individual dalam sebuah perusahaan. Kinerja karyawan sangat erat kaitannya dengan kepribadian karyawan. Kunci keberhasilan perusahaan dalam mengelola usahanya adalah dengan melibatkan karyawan pada setiap kegiatan. Keterlibatan karyawan merupakan komitmen yang dimiliki karyawan terhadap perusahaan. Karyawan dengan komitmen yang kuat akan menjalankan visi dan misi perusahaan serta memiliki kepedulian yang tinggi terhadap tugas yang menjadi tanggung jawabnya. Karyawan akan dengan senang hati mengerjakan tugasnya dan tidak menganggapnya sebagai beban. Secara psikologis karyawan yang mempunyai rasa memiliki terhadap perusahaan maka akan termotivasi untuk meningkatkan kinerja.

Faktor lain yang dapat mempengaruhi kinerja karyawan selain locus of control 
adalah kepuasan kerja. Kepuasan kerja merupakan persepsi seseorang terhadap bagaimana pekerjaan yang dilakukan oleh mereka dapat memberikan sesuatu yang dianggap penting, yang secara umum dapat diterima sebagi suatu yang penting dalam bidang perilaku. Upaya yang dapat dilakukan oleh atasan kepada karyawannya adalah dengan memberikan motivasi untuk menciptakan kepuasan kerja agar tercapainya kinerja karyawan yang sesuai dengan keinginan. Ketika Karyawan merasa terpuaskan, mereka akan memiliki kedeketan emosional yang cukup untuk menunjukkan empati, pengertian, respek, dan perhatian kepada perusahaan, namum ketika seorang karyawan tidak memiliki kepuasan dalam bekerja akan berdampak pada kinerja dalam perusahaan sehingga menyebabkan produktivitas kerja menurun.

Menurut Luthans (2005) tingkat kepuasan lebih mempengaruhi kinerja daripada kinerja mempengaruhi kepuasan sehingga pada penelitian ini variabel kepuasan kerja dipilih sebagai variabel perantara dalam mencapai kinerja karyawan. Berdasarkan hal tersebut, motivasi penelitian ini adalah untuk menguji kembali apakah dengan menggunakan teori yang sama tetapi dengan sampel dan lokasi yang berbeda akan menghasilkan hasil penelitian yang sama sehingga hasil penelitian dapat memperkuat teori yang ada dan bisa digeneralisasikan.

Berdasarkan hasil penelitian sebelumnya tentang

\section{METODE PENELITIAN}

\section{A. Metode Pengumpulan data}

Metode pengumpulan data yang digunakan dalam penelitian ini dengan menggunakan metode survey melalui pengisian kuesioner. Kuesioner yang diajukan dalam penelitian ini terdiri dari 27 pertanyaan atau pernyataan dengan menggunakan skala likert 1 sampai dengan 5 untuk setiap jawaban. Sample penelitian ini 100 karyawan tetap dan tidak tetap pada PT PNM Cabang Lampung dengan metode purposive sampling yang didasarkan pada kriteria tertentu yaitu karyawan tetap dan tidak tetap yang telah berkerja lebih dari 1 tahun.

\section{B. Variabel penelitian dan pengukuran variabel}

\section{Internal locus of control $(\mathbf{X})$}

Variabel internal locus of control diukur dengan menggunakan indikator Suka bekerja keras, memiliki insiatif yang tinggi, selalu berusaha untuk menemukan pemecahan masalah, selalu mencoba untuk berfikir seefktif mungkin dan selalu mempunyai persepsi bahwa usaha harus dilakukan jika ingin berhasil yang dikembangkan oleh Crider (1983). Indikator pertanyaan terdiri dari 7 item dengan point skala likert $1-5$ yang artinya sangat tidak setuju, tidak setuju, cukup setuju, setuju, dan sangat setuju.

2. Kepuasan Kerja $\left(\mathbf{Y}_{1}\right)$

Variabel kepuasan kerja diukur dengan menggunakan indikator Faktor psikologis, Faktor sosial, Faktor fisik, dan Faktor finansial yang dikembangkan oleh Sutrisno (2016). Indikator pertanyaan terdiri dari 12 item dengan point skala likert $1-5$ yang artinya sangat tidak setuju, tidak setuju, cukup setuju, setuju, dan sangat setuju.

\section{Kinerja Karyawan}

Variable kinerja karyawan dengan menggunakan indikator hasil kerja, inisiatif, kecekatan mental, disiplin waktu dan absensi yang dikembangkan Suwondo dan Sutanto (2015). Indikator pertanyaan terdiri dari 8 item dengan point skala likert $1-5$ yang artinya sangat tidak setuju, 
tidak setuju, cukup setuju, setuju, dan sangat setuju.

\section{Metoda Analisis data}

Alat analisis yang digunakan untuk menguji hipotesis adalah dengan metoda Structural Equation Model (SEM). Penggunaan model persamaan tersebut dengan aplikasi program Partial Least Squares (PLS) versi 3.0.m. Menurut Jogiyanto dan Abdillah (2014) PLS (Partial Least Square) adalah analisis persamaan struktural berbasis varian yang secara simultan dapat melakukan pengujian model pengukuran sekaligus pengujian model struktural. Pengukuran model (Outer Model) adalah pengujian yang dilakukan terhadap indikator yang membentuk variable laten eksogen. Model ini digunakan untuk menilai validitas dan reabilitas, sedangkan model structural digunakan untuk uji kausalitas atau pengujian hipotesis dengan model prediksi.

\section{a. Uji Validitas}

Uji validitas pada penelitian ini menggunakan Partial Least Square (PLS) dengan menguji validitas convergent dan discriminant dengan menggunakan kriteria sebagai berikut:

\section{b. Uji Reabilitas}

Uji reliabilitas digunakan untuk menguji apakah instrument penelitian bisa diandalkan untuk mengukur variabel tertentu pada sampel yang berbeda dilakukan dengan cara melihat Composite Reliability dan Cronbach
Alpha. Menurut Ghozali (2013) suatu konstruk dikatakan reliabel apabila memberikan nilai Composite Reliability $>$ 0,70 dan Cronbach Alpha > 0,60.

\section{c. Struktural Model}

Struktural model dalam PLS dievaluasi dengan menggunakan R-Square untuk konstruk dependen dan nilai koefisien path untuk uji signifikansi antar konstruk. Chin (1998) membagi batasan nilai $\mathrm{R}^{2}$ dalam tiga klasifikasi, yaitu 0,67 (kuat), 0,33 (moderat) dan 0,19 (lemah). Penilaian signifikansi model prediksi dalam pengujian inner model dapat dilakukan dengan melihat nilai probabilitas dan nilai t-stastistik. Dengan nilai probabilitas pada $\alpha=5 \%$. Nilai t-tabel untuk $\alpha=5 \%$ adalah 1,96. Sehingga hipotesis yang diajukan diterima dan signifikan jika nilai dari tstatistik > 1,96.

\section{HASIL DAN PEMBAHASAN}

\section{Analisis Data}

\section{a. Penilaian Outer Model}

Outer model digunakan untuk menilai validitas dan reabilitas model dengan menggunakan parameter model pengukuran melalui uji validitas konvergen, uji Validitas diskriminan, cronbach's alpha, composite reability dan uji $\mathrm{R}^{2}$. Hasil pengolahan data dapat dilihat pada gambar 1 berikut dengan menggunakan SmartPLS. 
Gambar 1.

Nilai Outer Model Original Sampel

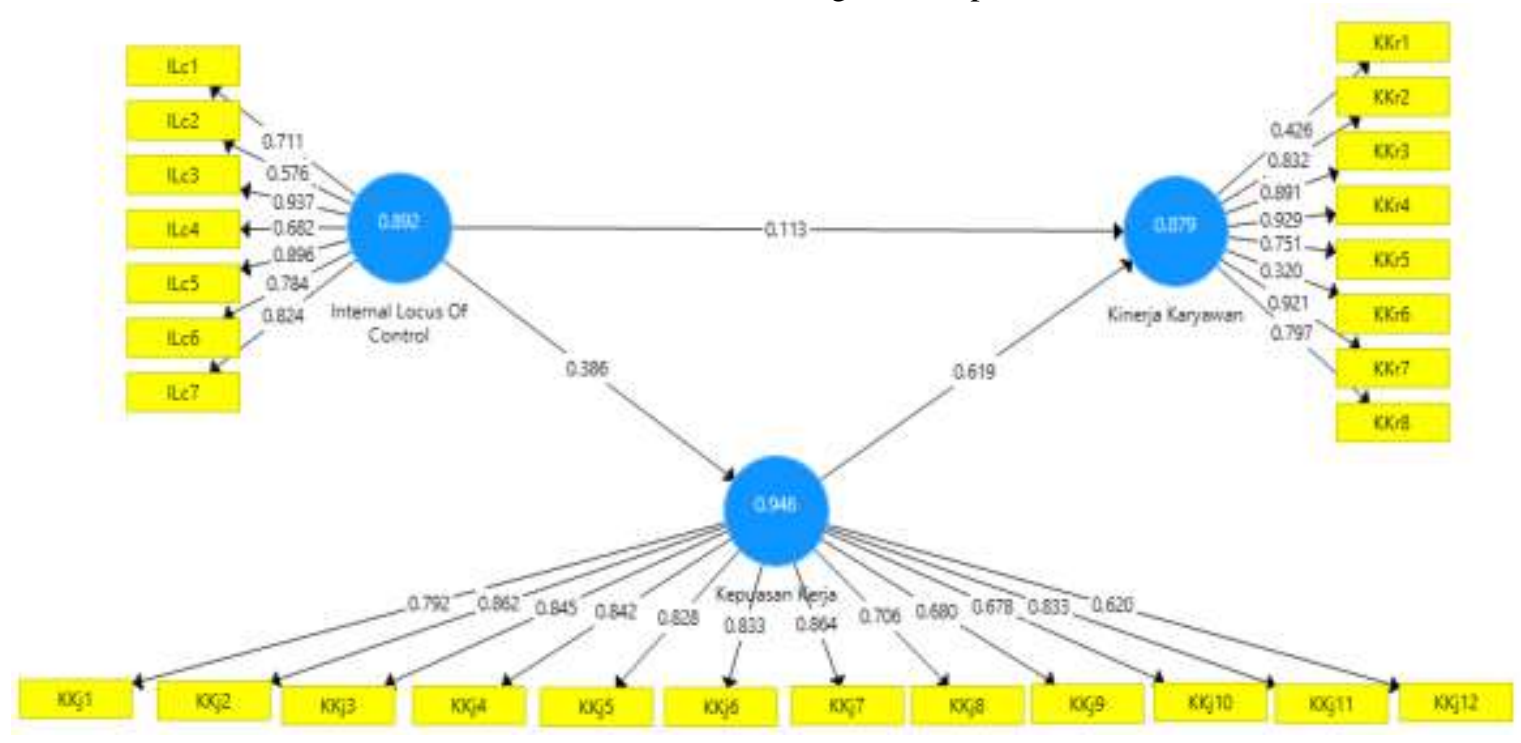

Sumber : data diolah SmartPLS, 2020.

Keterangan :

ILc : Internal Locus Of Control

$\mathrm{KKj} \quad$ : Kepuasan Kinerja

$\mathrm{KKr}$ : Kinerja Karyawan

Berdasarkan gambar $\mathrm{Ci}$ atas, Kinerja Karyawan. Batas Loading Factor menunjukan masih terdapat indikator yang pada penelitian ini adalah 0,7. Sehingga memiliki nilai Loading kurang dari 0,6, untuk dapat memenuhi kriteria tersebut sedangkan ukuran refleksif individual maka indicator ILc1, ILc2, ILc 4, KKj9, dikatakan tinggi apabila berkorelasi lebih KKj10, KKj12, KKr1, dan KKr6 dari 0,70 dengan konstruk yang diukur. dikeluarkan pada masing-masing konstruk Indikator tersebut adalah ILc1, ILc2, dan ILc yang selanjutnya dilakukan analisis kembali. 4 untuk variable Internal locus of control, Adapun output SmartPLS setelah dilakukan KKj9, KKj10, dan KKj12, untuk variabel eliminasi sebagai berikut:

Kepuasan Kerja, KKr1, dan KKr6 untuk 


\section{Gambar 2}

Nilai Outer Model Setelah Eliminasi

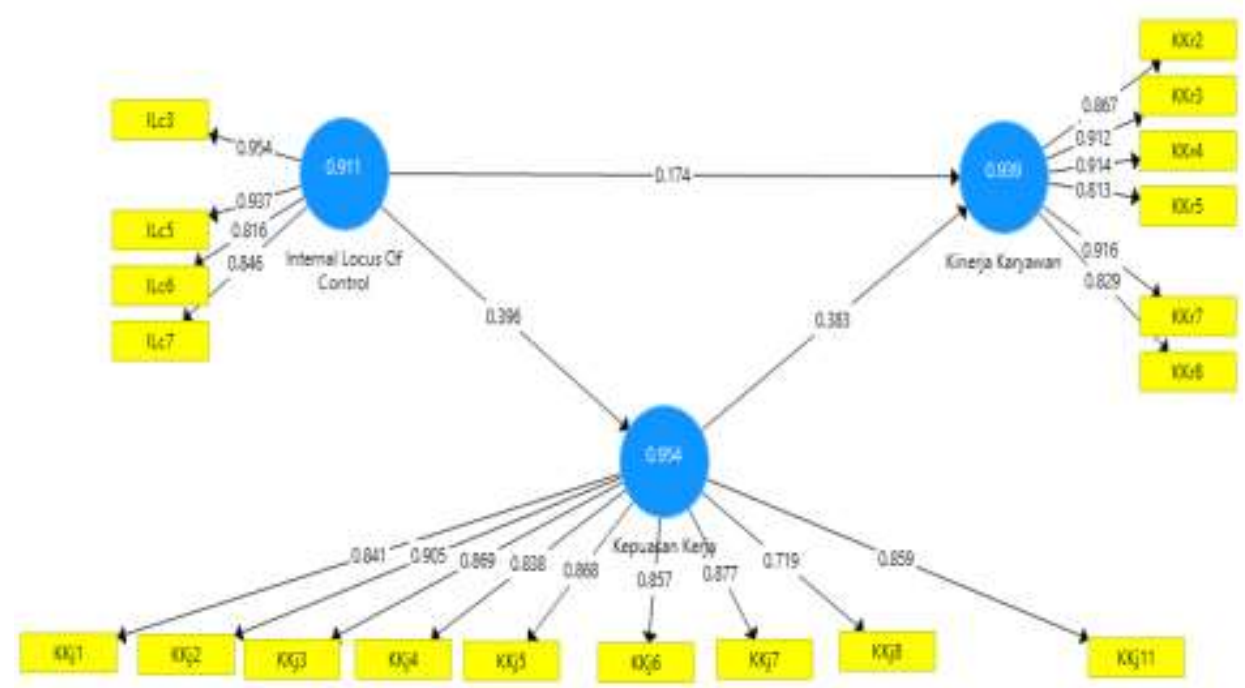

Sumber : data dioleh SmartPLS,2020

Gambar diatas menunjukkan nilai dari masing-masing in dikator setelah dilakukan estimasi kembali untuk memperoleh nilai loading factor dari masing-masing konstruk diatas 0,70 sebagai mana ditunjukkan pada gambar 2.

\section{b. Uji Validitas}

\section{1) Uji Validitas Konvergen}

Uji validitas konvergen dari model pengukuran dapat dilihat dengan menggunakan indikator reflektif berdasarkan nilai AVE. Uji validitas konvergen dapat dikatakan baik apabila memiliki nilai $\mathrm{AVE}>0,50$, dengan kata lain probabilitas indickator pada suatu konstruk masuk ke variabel lain lebih rendah (kurang dari 0,50) sehingga probabilitas indicator tersebut masuk kedalam konstruk yang lebih besar (Chin, 1995). Adapun hasil pengujian ini dapat dilihat pada tabel berikut:

Tabel 2.

AVE (Average Variance Extracted)

\begin{tabular}{lcc}
\multicolumn{3}{c}{ AVE (Average Variance Extracted) } \\
\hline Variabel Penelitian & AVE & Kriteria \\
\hline Internal Locus of Control (ILc) & 0,793 & Baik \\
Kepuasan Kinerja (KKj) & 0,722 & Baik \\
Kinerja Karyawan (KKr) & 0,768 & Baik \\
\hline
\end{tabular}

Sumber : data dioleh SmartPLS,2020

Berdasarkan hasil pada tabel 2, menunjukkan bahwa nilai AVE > 0,70, dan dapat diterima sebagai pengukur sehingga dapat dikatakan bahwa konstruk internal locus of control, kepuasan kerja, dan kinerja karyawan memiliki nilai validitas yang telah memenuhi kriteria variabel laten penelitian.

\section{2) Uji Validitas Diskriminan}

Uji Validitas diskriminan diukur dengan melihat nilai cross loading. Cross loading digunakan untuk melihat apakah 
masing-masing konstruk pada setiap indikator memiliki validitas diskriminan yang memadai. Output smartPLS untuk cross loading pada masing-masing konstruk dapat dilihat pada tabel 3.

Tabel 3.

Validitas diskriminan dengan menggunakan cross loading

\begin{tabular}{|c|c|c|c|}
\hline Indikator & Ilc & KKJ & $\mathrm{KKr}$ \\
\hline ILc3 & 0.954 & 0.398 & 0.336 \\
\hline ILc5 & 0.937 & 0.385 & 0.287 \\
\hline ILc6 & 0.816 & 0.266 & 0.292 \\
\hline ILc7 & 0.846 & 0.349 & 0.242 \\
\hline $\mathrm{KKj1}$ & 0.226 & 0.841 & 0.167 \\
\hline $\mathrm{KKj} 2$ & 0.240 & 0.905 & 0.238 \\
\hline $\mathrm{KKj} 3$ & 0.345 & 0.869 & 0.489 \\
\hline $\mathrm{KKj} 4$ & 0.346 & 0.838 & 0.343 \\
\hline KKj5 & 0.226 & 0.868 & 0.207 \\
\hline KKj6 & 0.407 & 0.857 & 0.511 \\
\hline $\mathrm{KKj} 7$ & 0.402 & 0.877 & 0.348 \\
\hline KKj8 & 0.229 & 0.719 & 0.290 \\
\hline $\mathrm{KKj} 11$ & 0.412 & 0.859 & 0.525 \\
\hline $\mathrm{KKr} 2$ & 0.382 & 0.312 & 0.867 \\
\hline KKr3 & 0.292 & 0.415 & 0.912 \\
\hline $\mathrm{KKr} 4$ & 0.247 & 0.426 & 0.914 \\
\hline KKr5 & 0.257 & 0.382 & 0.813 \\
\hline $\mathrm{KKr} 7$ & 0.244 & 0.424 & 0.916 \\
\hline
\end{tabular}

Sumber : data diolah dari SmartPLS,2020

Berdasarkan tabel 3, diketahui hasil estimasi cross loading menunjukkan nilai korelasi indikator pada masing-masing konstruk lebih tinggi dibandingkan nilai korelasi dengan konstruk lainnya. Hal ini berarti konstruk laten mampu memprediksi indikator pada blok mereka lebih baik dibandingkan dengan indicator pada blok yang lain.

\section{c. Uji Reabilitas}

Uji reabilitas dilakukan dengan melihat nilai composite reability dan cronbach alpa. Suatu vaiabel dikatakan reliable apabila memberikan nilai composite reability > 0,70 dan cronbach alpa > 0.60 (Ghozali, 2013). Hasil estimasi dari masing-masing konstruk dapat dilihat pada tabel 4 berikut :

Tabel 4

Composite reability dan Cronbach Alpa

\begin{tabular}{lcc}
\hline \multicolumn{1}{c}{ Variabel } & Coposite Reability & Cronbachs Alpa \\
\hline Internal Locus of Control (ILc) & 0.938 & 0.911 \\
Kepuasan Kinerja (KKj) & 0.959 & 0.954 \\
Kinerja Karyawan (KKr) & 0.952 & 0.939 \\
\hline
\end{tabular}

Sumber : data diolah SmartPLS, 2020

Berdasarkan tabel diatas, diketahui bahwa keseluruhan konstruk dalam penelitian ini merupakan konstruk yang realiabel, hal ini ditunjukkan melalui nilai composite reability $>0.70$ dan nilai cronbach alpa $>0.60$ sehingga dapat disimpulkan bahwa semua konstruk memiliki nilai reabilitas yang baik.

\section{d. Pengukuran Model Struktural}

Pengujian terhadap model struktural dilakukan untuk menguji hipotesis dengan melihat nilai coefficient of determination $\left(\mathrm{R}^{2}\right)$ yang merupakan uji goodness-fit model untuk konstruk 
dependen. Hasil pengujian dapat dilihat pada tabel berikut :

Tabel 5

Uji Coefficient of determination $\left(\mathrm{R}^{2}\right)$

\begin{tabular}{lc}
\hline & $\mathrm{R}$ Square \\
\hline Internal Locus of Control & \\
Kepuasan Kerja & 0.157 \\
Kinerja Karyawan & 0.230 \\
\hline \multicolumn{2}{c}{ Sumber : data diolah dari SmartPLS,2020 }
\end{tabular}

Hasil pengujian pada tabel 5 control dan kepuasan kerja mampu menunjukkan pengaruh internal locus of menjelaskan variable kinerja karyawan control terhadap kepuasan kerja sebesar 23\% sedangkan sisanya sebesar $77 \%$ menghasilkan nilai $\mathrm{R}^{2}$ sebesar 0.157 , hal ini dapat dijelaskan oleh variable laten lain yang menunjukkan bahwa variabilitas konstruk tidak dijelaskan dalam penelitian ini.

kepuasan kerja dapat dijelaskan atau dipengaruhi oleh variabilitas kontruk internal locus of control sebesar $15.7 \%$ sedangkan sisanya $84.3 \%$ dijelaskan oleh variable lain yang tidak dijelaskan dalam penelitian ini. Nilai $\mathrm{R}^{2}$ pada kinerja karyawan sebesar 0.230 menunjukkan bahwa kemampuan variabel internal locus of

\section{d. Pengujian Hipotesis}

Hasil pengolahan data untuk pengujian hipotesis secara langsung maupun tidak langsung dengan menggunakan smartPLS 3.0 sebagaimana disajikan pada tabel 6 berikut:

Tabel 6

Hasil Pengujian Hipotesis Secara Langsung

\begin{tabular}{|c|c|c|c|c|c|}
\hline Hipotesis & Deskripsi Hipotesis & $\begin{array}{l}\text { Original } \\
\text { Sampel } \\
\text { (O) }\end{array}$ & $\begin{array}{c}\mathrm{T} \\
\text { Statistik }\end{array}$ & $\begin{array}{c}\mathrm{T} \\
\text { Tabel }\end{array}$ & Keputusan \\
\hline H1 & $\begin{array}{l}\text { Internal locus of } \text { control } \\
\text { berpengaruh positif } \\
\text { kinerja karyawan }\end{array}$ & 0.174 & 1.338 & 1.96 & $\begin{array}{c}\text { Tidak } \\
\text { Terdukung }\end{array}$ \\
\hline $\mathrm{H} 2$ & $\begin{array}{l}\text { Internal locus of control } \\
\text { berpengaruh positif terhadap } \\
\text { kepuasan kerja }\end{array}$ & 0.396 & 4.003 & 1.96 & Terdukung \\
\hline H3 & $\begin{array}{l}\text { Kepuasan Kerja berpengaruh positif } \\
\text { terhadap kinerja karyawan }\end{array}$ & 0.383 & 2.428 & 1.96 & Terdukung \\
\hline
\end{tabular}

Sumber: data diolah smartPLS (2020)

\section{Pembahasan}




\section{1) Pengaruh Secara Langsung}

\section{Pengaruh Internal Locus of Control Terhadap kinerja Karyawan}

Hasil pengujian pada H1 menunjukkan bahwa internal locus of control memiliki hubungan positif tidak signifikan terhadap kinerja karyawan yang dibuktikan melalui nilai koefisien jalur sebesar 0.174 dan nilai T-statistik 1.338 lebih kecil dari T-tabel 1.96 pada tingkat signifikansi $5 \%$. Sehingga dapat disimpulkan bahwa H1 tidak Terdukung. Hal ini menunjukkan bahwa ketika seseorang beranggapan bahwa segala sesuatu peristiwa yang dialami terjadi karena tindakan individu itu sendiri, maka belum tentu tindakan tersebut akan meningkatkan kinerja karyawan.

Pengaruh Internal Locus of Control Berpengaruh Positif Terhadap Kepuasan Kerja

Hasil pengujian pada $\mathrm{H} 2$ menunjukkan bahwa internal locus of control memiliki hubungan positif dan signifikan terhadap kepuasan kerja yang dibuktikan melalui nilai koefisien jalur sebesar 0.396 dan T-Statistik 4.003 lebih besar dari nilai $\mathrm{T}$-tabel 1.96 pada tingkat signifikansi 5\%, sehingga dapat disimpulkan bahwa $\mathbf{H 2}$ terdukung. Hal ini menunjukkan bahwa ketika seseorang dengan internal Locus of control beranggapan bahwa segala sesuatu yang diperoleh berasal dari usaha mereka sendiri, tanpa tergantung orang lain maka mereka akan merasa puas dengan hasil pekerjaannya karena kendali pada diri serta kemampuannya berkontribusi atas keberhasilan dalam bekerja.

\section{Pengaruh Kepuasan Kerja terhadap Kinerja karyawan \\ Hasil penelitian pada $\mathrm{H} 3$} menunjukkan bahwa kepuasan kerja memiliki hubungan positif signifikan terhadap kinerja karyawan yang dibuktikan melalui nilai koefisien jalur sebesar 0.383 dan t-statistik 2.428 lebih besar dari t-tabel 1.96 pada tingkat signifikansi 5\%, sehingga dapat disimpulkan bahwa $\mathbf{H 3}$ terdukung. Hal ini menunjukkan bahwa semakin tinggi tingkat kepuasan kerja karyawan mampu membantu meningkatkan kinerja yang dapat ditunjukan melalui tingkat kehadiran dan prestasi kerja yang dapat dijadikan sebagai indikator dalam menilai perubahan pada unit organisasi.

Tabel 7

Hasil Pengujian Hipotesis secara Tidak Langsung

\begin{tabular}{cllll}
\hline Hipotesis & \multicolumn{1}{c}{ Deskripsi Hipotesis } & T Statistik & P Value & Keputusan \\
\hline H4 & $\begin{array}{l}\text { Internal locus of control berpengaruh } \\
\text { positif terhadap kinerja karyawan melalui } \\
\text { kepuasan kerja }\end{array}$ & 2.107 & 0.018 & Terdukung \\
& & & & \\
\end{tabular}

Sumber: data diolah smartPLS (2020)

2) Pengaruh Secara Tidak Langsung (Intervening)

\author{
Pengaruh Internal Locus Of Control \\ Terhadap Kinerja Karyawan dengan \\ Kepuasan Kerja Sebagai Variable \\ Pemediasi
}

Hasil penelitian pada $\mathrm{H} 4$ menunjukkan bahwa pengaruh langsung internal locus of control terhadap kinerja karyawan berpengaruh positif tidak signifikan sedangkan pengaruh tidak langsung menunjukkan nilai ordinal sampel 0.152 yang berarti bahwa 
memiliki pengaruh positif dan T-statistik 2.107 lebih besar dari T-tabel 1.96 pada tingkat signifikansi 5\%. Menurut Zhao et.al. (2010) yang juga mengembangkan jenis mediasi dari Baron dan Kenny (1986) menunjukkan bahwa ketika pengaruh langsung tidak signifikan dan pengaruh secara tidak langsung signifikan maka dapat dikatakan bahwa variable $\mathrm{M}$ mampu memediasi pengaruh variabel $\mathrm{x}$ terhadap variabel $\mathrm{y}$ yang memiliki pengaruh indirect-only mediation yaitu kepuasan kerja mampu memediasi hubungan antara internal locus of control terhadap kinerja karyawan. Sehingga H4 Terdukung. Hal ini menunjukkan bahwa Jika seorang karyawan memiliki kecenderungan terhadap internal locus of control akan meyakini atas kemampuan dirinya sendiri untuk dapat menyelesaikan setiap permasalahan yang akan menimbulkan kepuasan kerja dan diharapkan dapat meningkatkan kinerja karyawan.

\section{KESIMPULAN}

Berdasarkan hasil penelitian dan pembahasan dapat ditarik kesimpulan bahwa

1. Internal locus of control tidak berpengaruh terhadap kinerja karyawan. Hal ini tidak mendukung hipotesis.

2. Internal locus of control berpengaruh positif signifikan terhadap kepuasan kerja. Hal ini mendukung hipotesis.

3. Kepuasan kerja berpengaruh positif signifikan terhadap kinerja karyawan. Hal ini mendukung hipotesis.

4. Kepuasan kerja memediasi hubungan antara internal locus of control terhadap kinerja karyawan,

\section{DAFTAR PUSTAKA}

Baron, R. M., \& Kenny, D. A. (1986). The moderator-mediator variable distinction in social psychological research: Conceptual, strategic, and statistical considerations. Journal of personality and social psychology, 51(6), 1173.

Chin, W.C. and Todd, P.A. 1995. On the Use, Usefulness and Ease of Use of Structural Equation Modelling in MIS Research: A Note of Caution. MIS Quartely, Vol. 19 No. 2, pp 234-46.

Crider, A.B. 1983. Psychology. Illionis : Scot Foreshman and Company.

Ghozali, Imam. 2013. Aplikasi Analisis Multivariate dengan Program IBM SPSS.

Edisi Ketujuh. Semarang: Badan Penerbit Universitas Diponegoro

Isnanto, Taufik. Mei Indrawati, dan Muninghar. 2020. Analisis Pengaruh Budaya Organisasi,Locus of Control, Stres kerja Terhadap Kinerja dan Kepuasan Kerja Sebagai Variabel Intervening. JMM Online Vol. 4 No Pegawai. 5 Mei, PP 789803

Jogiyanto, H,M. dan Abdillah Willy. 2014. Konsep dan Aplikasi PLS (Partial Least Square) untuk penelitian empiris. BPFE Universitas Gajah Mada.

Khairiyah, Nur Syaima Annisa. 2013. Pengaruh Kepuasan Kerja, Gaya Kepemimpinan, dan Motivasi Kerja Terhadap Kinerja Karyawan Pada PT. Nutricia Indonesia Sejahtera. Jurnal Proceeding PESAT (Psikologi, Ekonomi, Sastra, Arsitektur \& Teknik Sipil). Volume Oktober. ISSN: 18582559. Universitas Gunadarma. 
Kumaladewi, Ajeng Putri dan Rahardja, Edy. 2016. Pengaruh Locus Of Control,

Employee Engagement dan Kepuasan Kerja Terhadap Kinerja Karyawan PT.

Taspen Kantor Cabang Utama Semarang. Jurnal Manajemen Analisis.

Luthans, F., Avolio, B., Walumbwa, F., \& Li, W. 2005. The psychological capital of Patten M.Dennis. 2005. An Analysis of The Impact of Locus of Control on Internal Auditor Job Performance and Satisfaction. Managerial Auditing Journal, Vol. 20 No. 9, pp. 1016-1029.

Sutrisno, Edy. 2016. Manajemen Sumber Daya Manusia. Bandung: PT. Mulia Kencana Semesta

Suwondo, D. I., \& Sutanto, E. M., 2015. Hubungan lingkungan kerja, disiplin kerja, dan kinerja karyawan. Jurnal Manajemen Dan Kewirausahaan, 17(2), 135- 144.

Zhou X., Lynch Jr, J.G., Chen Q. 2010. Reconsidering Baron and Kenny : Myths and Truths about Mediation Analysis. Journal of Consumer Research. Vol 37, pp.197-206 